\title{
Notes on Operations Using Comparative Online Journal Usage Studies to Assess the Big Deal
}

\section{By Cecilia Botero, Steven Carrico, and Michele R. Tennant}

This paper analyzes the comparative findings of two studies undertaken at the University of Florida Libraries comparing online journal usage statistics derived from COUNTER-compliant publishers. The analyses conducted in 2005 and 2006 were not intended to be rigorous scientific studies. Instead, the statistical assessments were intended as tools for determining trends in the costs and use of online journals at the University of Florida. The studies also explored the relationship between the large publisher online journal packages (the so-called Big Deals often licensed through consortia arrangements) and online journal usage, and the effects of Big Deal packages on library budgets.

\section{Introduction}

L ibraries consistently seek meandingful methods through which they can assess the value of their collection and the remote resources to which they provide access. They want to know how well the collection is meeting users' needs, in addition to demonstrating accountability for the financial resources with which they are entrusted. One metric utilized for decades is use, yet use in the online environment has been difficult to measure. This is changing as information providers have begun to provide use data that complied with the COUNTER guidelines. COUNTER stands for Counting Online Usage of NeTworked Electronic Resources, and "is an international initiative to improve the reliability of online usage statistics." "This paper examines data provided by COUNTERcompliant publishers for e-content in the University of Florida Libraries to study trends in costs and use. While specific to the University of Florida, the approach described can be applied in other libraries.

The fiscal year at the University of Florida (UF) Libraries begins on July 1 and ends the following year on June 30. At the beginning of each fiscal year a new materials budget is drafted by a group consisting of representatives and librarians from Library Director's Office and both the Collection Management and Acquisitions Departments. In July 2005, the materials budget for Fiscal Year (FY) 2005/2006 issued by this group coincided with the first meeting of a team of four librarians examining an aggregation of online journal usage statistics. With the new materials budget in hand, the four-member team (three librarians from the University of Florida Health Science Center Libraries and one from the University of Florida Smathers Libraries) noted that over half of the approximate $\$ 8$ million materials budget for the UF Libraries was devoted to acquiring electronic resources. Thus the team decided to converge the examination of online journal usage statistics with a summary of budgetary expenditures to devise a study of cost-effectiveness, that is, compare expenditures of online journal packages, concentrating on the larger publishers, with the usage statistics garnered from each package. Besides launching a study on the cost-effectiveness of online journals, the team set several smaller but important goals of the project. These objectives included assessing 
or reconfirming patron preferences for various online journal packages, and investigating how the Big Deals (large online journal packages) were affecting materials expenditures and traditional library collection building.

\section{Prevalence of Online Resources and Trends in the University of Florida Libraries}

Online resources have become the primary mode of accessing and collecting information for most academic and health sciences library users, particularly in the fields of biomedicine and the sciences. ${ }^{2}$ Consequently, as these libraries offer more electronic resources to better serve their patrons, usage patterns are changing dramatically. Readily available electronic resources have changed the approach and even the methodology users apply when conducting research. Libraries, attempting to keep up with the increasing desires for databases and online journals, are spending a growing percentage of their materials budgets on acquiring these electronic resources. According to Kyrillidou of the Association of Research Libraries (ARL), "with a median of more than $\$ 5.5$ million spent on serials in 2003/04 and an increasing portion of these expenditures devoted to electronic resources (30 percent of the library materials as of the latest count), libraries appear to be catering to their users' never-ending lust for delivery of information to the desktop." 3

The trend of academic, health sciences, and medical libraries devoting more of their materials budgets to electronic resources is substantiated by a review of the materials budgets at the UF Libraries, specifically the budgets of the University of Florida's Health Science Center Libraries (HSCL) and the University of Florida Smathers Libraries (Smathers). HSCL's expenditures for print books, print serials, and electronic resources in each fiscal year spanning four years, FY2002/2003 to FY2005/2006, are shown in figure 1 , and the breakdown of the materiSmathers are shown in figure 2 ; expenditures for FY2006/2007 are shown as projected within both charts. Despite the disproportionate size of the two budgets, the charts show a similar pattern. During the four-year period FY2002/2003 through FY2005/2006, expenditures for print books and print serials remained constant as expenditures for electronic resources increased significantly. Electronic resources at HSCL are primarily online journals, as expenditures for electronic books and other electronic media are comparably low. In FY2005/2006, the HSCL spent approximately 51 percent of an annual \$2.1-million materials budget on the acquisitions of electronic resources, rising from 12 percent of the budget from three years earlier. In FY2005/2006, expenditures for print journals were approximately 43 percent of the budget, a drop from 81 percent in FY2002/2003. The same pattern is seen at Smathers. In FY2005/2006, approximately 50 percent of a $\$ 7.4$ million materials budget was spent on electronic resources, a rise from 21 percent of the FY2002/2003 budget. Simultaneously, the percentage als budgets in the same period for

of the materials budget for print journals decreased from 53 percent to 33 percent between FY2002/2003 and FY2004/2005. Both charts show only a minor decline in monograph expenditures. The dramatic shift in expenditures is between the budgets for print journals and for electronic resources. Both libraries are spending more on online resources because library patrons consistently prefer using the electronic format to print.

The three largest Big Deal packages (Elsevier, Wiley, and Springer/ Kluwer) at the UF Libraries also are having a more than significant impact on the materials budgets. The UF Libraries spent $\$ 2.6$ million on these three packages in FY2005/2006, representing approximately 27 percent of the total materials budget, and 54 percent of the more than $\$ 4.8$ million spent on electronic resources (see table 1). Despite the hefty annual budgetary outlay for these types of packages, the libraries did not know if use justified the expenditures.

To answer the question, "Does use justify expenditures?" the team undertook a study to examine the cost-effectiveness of online journals, especially those received through the Big Deal packages, using vendor and publisher supplied usage statistics.

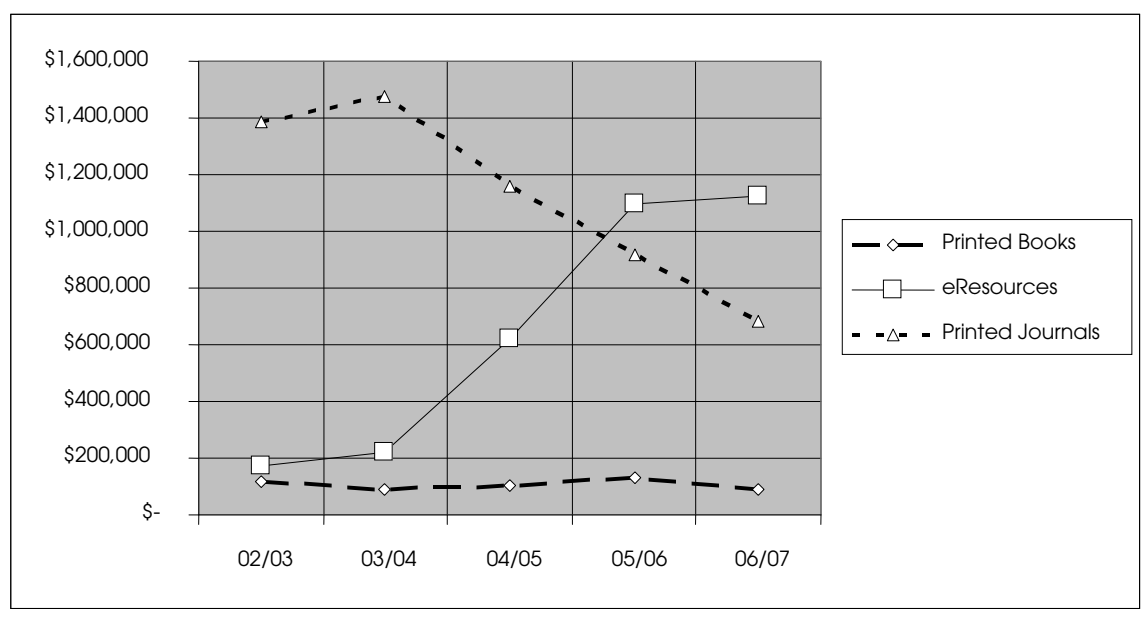

${ }^{\text {}}$ Expenditures for FY2006/07 are projections.

Figure 1. HSCL material expenditures FY2002/2003 through FY2006/2007 


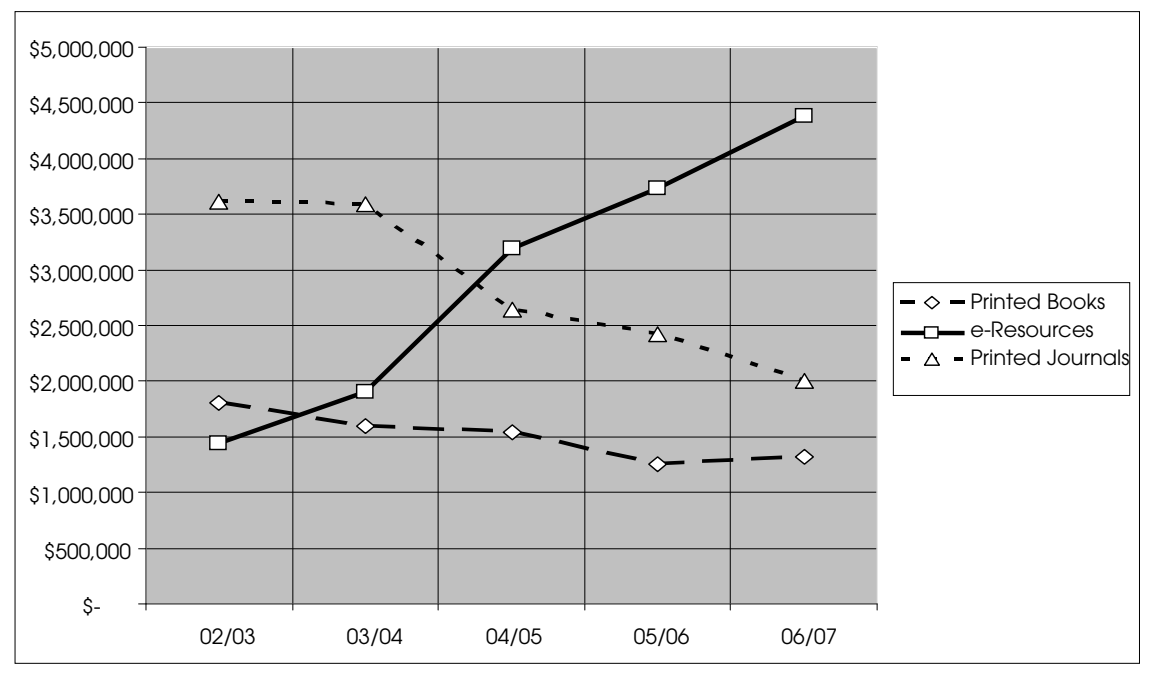

*Expenditures for FY2006/07 are projections.

Figure 2. Smathers material expenditures FY2002/2003 through FY2006/2007

Table 1. Materials expenditures FY2005/2006

\begin{tabular}{|c|c|c|c|}
\hline & HSCL & Smathers & Total \\
\hline Total materials expenditures & $\$ 2,148,120$ & $\$ 7,400,994$ & $\$ 9,549,114$ \\
\hline Total e-resource expenditures & $\$ 1,097,225$ & $\$ 3,729,440$ & $\$ 4,826,665$ \\
\hline Total expenditures for Big Deals & $\$ 686,130$ & $\$ 1,934,932$ & $\$ 2,621,062$ \\
\hline $\begin{array}{l}\% \text { of total materials expenditure } \\
\text { devoted to e-resources }\end{array}$ & $51 \%$ & $50 \%$ & $51 \%$ \\
\hline $\begin{array}{l}\text { \% of total e-resources expenditures } \\
\text { devoted to "Big Deal" packages }\end{array}$ & $63 \%$ & $52 \%$ & $54 \%$ \\
\hline
\end{tabular}

Cost-effectiveness is defined as "the degree to which the decision making and planning in an organization have resulted in favorable or unfavorable ratios of advantages to costs." ${ }^{.4}$ Other goals of the study were to gather information to help collection management librarians make informed decisions on future materials acquisitions, and to better organize usage statistics for individual disciplines, which could be reported to librarians, faculty, and researchers.

\section{Setting}

The main campus of UF, a major public, land-grant, and research university, is located in Gainesville, Florida. UF is among the nation's most academically diverse public universities, with sixteen colleges offering more than one hundred degree programs, an enrollment of more than 42,000 undergraduates, and more than 10,000 full-time graduate students. The university includes more than one hundred research, service, and education centers, bureaus, and institutes, and has a teaching faculty of more than 3,000. A number of off-campus research-based sites, including the Whitney Laboratory for Marine Bioscience in St. Augustine, and agricultural research and extension sites are located throughout the state.

The UF Libraries form the largest information resource system in Florida, containing more than four million volumes and offering access to thousands of full-text electronic journals. The university library system is composed of three main libraries: the Smathers Libraries, the Lawton Chiles Legal Information Center, and the HSCL, with a corresponding branch, the Borland Library, located in Jacksonville, Florida. Only two of these principal libraries on campus are included in this study: the Smathers Libraries (the primary campus libraries for clients in the social sciences, arts, humanities and general sciences) and the HSCL, which has the most comprehensive academic health collections in the Southeast.

The Smathers Libraries' collections match the educational and research needs of the majority of students and faculty at the university. The HSCL serve the six colleges of the Health Science Center: dentistry, medicine, nursing, pharmacy, public health and health professions, and veterinary medicine. At UF, all campus libraries collaborate very closely, particularly in the area of collection development, and have numerous consortial agreements with each other and with other state university libraries throughout Florida. The need for close collaboration in collection development and management is particularly true for the HSCL and the Marston Science Library (MSL), which holds the general science collection and is part of the Smathers Libraries. The collection managers of the two libraries (HSCL and Smathers) collaborate to avoid duplication while offering unique but essential online and print resources. As part of the UF and part of the greater UF Libraries, both Smathers and HSCL benefit from UF's membership in the statewide university consortia.

\section{Literature Review}

In 2001, Frazier, director of libraries at the University of Wisconsin, Madison, coined the term "Big Deal" to describe the bundled online journal packages offered by the large publish- 
ers and subscribed to by escalating numbers of libraries. ${ }^{5}$ These Big Deal packages are often offered and distributed through consortial arrangements. Frazier denounced such deals as unfair for libraries because they must accept an entire package of journals and cannot select individual titles, and because the agreements too often force a growing dependence upon the publishers and bind the libraries into long-term, unequal business relationships. Instead, he recommended that libraries fight back by investing in new models of scholarly communication and publishing, such as the Scholarly Publishing and Academic Resources Coalition (SPARC) initiative. ${ }^{6}$ Four years later, Frazier expanded this argument by observing that "the Big Deals are not sustainable." ${ }^{\prime 7}$ According to Frazier, this business model cannot sustain itself long-term because "all Big Deals are based on the presumption that libraries can continually increase expenditures for journals and that publishers must have perpetual revenue growth. This future cannot and will not happen." ${ }^{8}$ Helfer agreed with this view and cited examples of renegotiations and cancellations of the Big Deal that occurred at the libraries of Cornell University, Harvard, and the University of California Library System. ${ }^{9}$ Promoting new models of scholarly communication, Helfer concluded "librarians are realizing that to continue to provide the scholarly journals their faculty write in and often edit, they will have to develop better economic approaches, and that the traditional models must change for them to do so." ${ }^{.10}$

In addition to advocating the development of new models of scholarly communication, some librarians are urging libraries and consortia to negotiate better package deals with the large publishers. Gatten and Sanville referred to these negotiations as an orderly retreat. ${ }^{11}$ They cited the experience of the library consortium OhioLINK renegotiating deals with large publishers by applying the concept of an "incremental attrition of content and annual cost without bringing the relationship to a crisis or destroying the essential benefits to both parties." ${ }^{\text {12 }}$ Applying usage pattern data and other statistics to inform reduction in the number of under-accessed titles received through the Big Deals, OhioLINK's "cost for content" model "allows for an annual reduction from the next year's planned value of the license by an amount equivalent to the percentage of use that titles selected for discontinuation represent." ${ }^{\prime 3}$

Not all librarians have seen problems with Big Deal agreements. Ebert, a director at a research library in upstate New York that is a member of a consortium, considered a Big Deal contract for Science Direct to be cost-effective, stating "we are getting significant added value for our dollars and our users are pleased with access to an enriched range of resources," and concluding that "our usage levels indicate growth of use and a continuing reduction in the cost-per-article." ${ }^{\prime 4}$

A number of presentations were given about Big Deal packages, especially as they pertain to library consortia, at the 2005 Charleston Conference. Bucknall defined the Big Deal and the attractive rates smaller academic libraries receive compared to those received by larger academic libraries, and discussed how "real costs" should be factored into the equation, together with patron satisfaction and cooperative sharing. ${ }^{15}$ He noted that, "each school will have to carefully weigh the many pros and cons before making a decision to participate in any specific Big Deal."16 Bucknall then described how a group of thirty-eight institutions formed a buyer's club for electronic resources and, through this consortium, made 2,300 titles available to users and saved approximately $\$ 70$ million. Bucknall stated that, although these numbers are impressive sounding, the key issues are whether the individual institutions' patrons are benefiting and whether usage statistics prove the cost effectiveness of the package.

Price identified the pros and cons of the Big Deal by using the contract for Elsevier's ScienceDirect package with the Statewide California Electronic Library Consortium as an example. ${ }^{17}$ Price pointed out the negative side of the Big Deal and how the consortium's institutions are being locked into packages, especially publisher-fixed subject collections, which could prevent individual selection of journal titles and create collection gaps and overpayment. The appealing aspects of these large deals include the many additional journals otherwise unaffordable individually, and flexibility in adding or deleting titles based on shared title lists and user statistics. Price recommended that libraries negotiate with the publishers on the deals and concluded that "sharing use data to build the optimal shared access list represents one way consortium members can work together to improve the quality of a product for their users." 18

Other authors have studied the use of e-resources. Franklin and Plum conducted a Web-based survey of 15,000 library users at four academic health science libraries and discovered "there were approximately four remote networked electronic services users for each in-house user. This ratio was even higher for faculty, staff and research fellows, where more than five remote users for each in-house user were recorded."19 At the Medical College of Wisconsin Libraries, Kraemer determined that "electronic usage has quadrupled in four years, while re-shelving of print journals has dropped by more than half." ${ }^{\prime 20}$ Other studies reveal increased use of electronic resources as well as patrons' preference for electronic resources. At Drexel University's Hagerty Library, Montgomery and King conducted an analysis of the effect of library's shift to electronic journals on staff and costs, 
concluding, "when all costs are considered, electronic journals are more cost-effective on a per use basis." ${ }^{21}$ Stemper and Jaguszewski recommended that libraries should examine usage statistics in a cost-effective manner, stating that "to better meet user needs and make every dollar count, librarians need apply the same sorts of data analysis to e-journals as they have traditionally applied to print journals, focusing on usage statistics, cost and cost per use." ${ }^{22}$

\section{Data Collection}

The UF Libraries have numerous license agreements arranged directly with publishers and, as a member of the State University Libraries system, benefit from numerous statewide consortial deals. Through these journal subscriptions and consortial agreements, the UF Libraries receives access to more than 40,000 full-text journals. With a budget of more than $\$ 4.8$ million for electronic resources, coupled with an established growth in library patron and off-campus use of electronic resources, a full-scale examination of usage statistics became imperative. To that end, the four-person team conducted two studies with the same primary objective: compare usage statistics with materials expenditures to determine if the online journals received from the Big Deals are cost-effective.

Both studies focused on vendorsupplied usage statistics derived from library patrons downloading full-text articles. The initial study, conducted in 2005 , used data from the previous year to establish a benchmark. The statistics were received from COUNTER-compliant publishers for the calendar year 2004, and the study did not incorporate non-COUNTERcompliant titles. Online titles with no hits were verified for subscription and ready access; online titles preventing access were removed from further consideration. The team categorized the titles into the broad disciplines of social science, humanities, science, and clinical medicine. The complete list of titles was then used to generate a random sample of 682 titles (10 percent) of the journal total, representing a .04 degree of accuracy. The second study was conducted in 2006 using data derived from calendar year 2005. Usage statistics from the same 682 titles used in the random sample from the first study were employed as a method of comparison between the two studies.

\section{Findings}

Through data analysis of the 2005 and 2006 studies, four major trends could be discerned:

- full-text downloads increased in all disciplines from 2004 to 2005.

- the general disciplines expose distinct differences in usage patterns.
- the usage variants lead to more cost-effective expenditures in some disciplines over others.

- the increased purchase of electronic resources has had a definite effect on the entire library materials budget and on the process of collection development.

In 2004, library users made 1,287,108 full-text downloads from all online journals at the UF Libraries; in 2005 , they made $1,699,442$ fulltext downloads-an increase of 32 percent. Looking at the sample data for the two years, one can see that significantly more full-text downloads occurred in the basic sciences and clinical medicine, with a lower number of downloads from online journals in the Smathers' subject areas of humanities and social sciences (see figure 3). Within this 682 title sample set, the difference in percentages between full-text downloads in the basic sciences and clinical medicine versus downloads in the humanities and social sciences is staggering. In

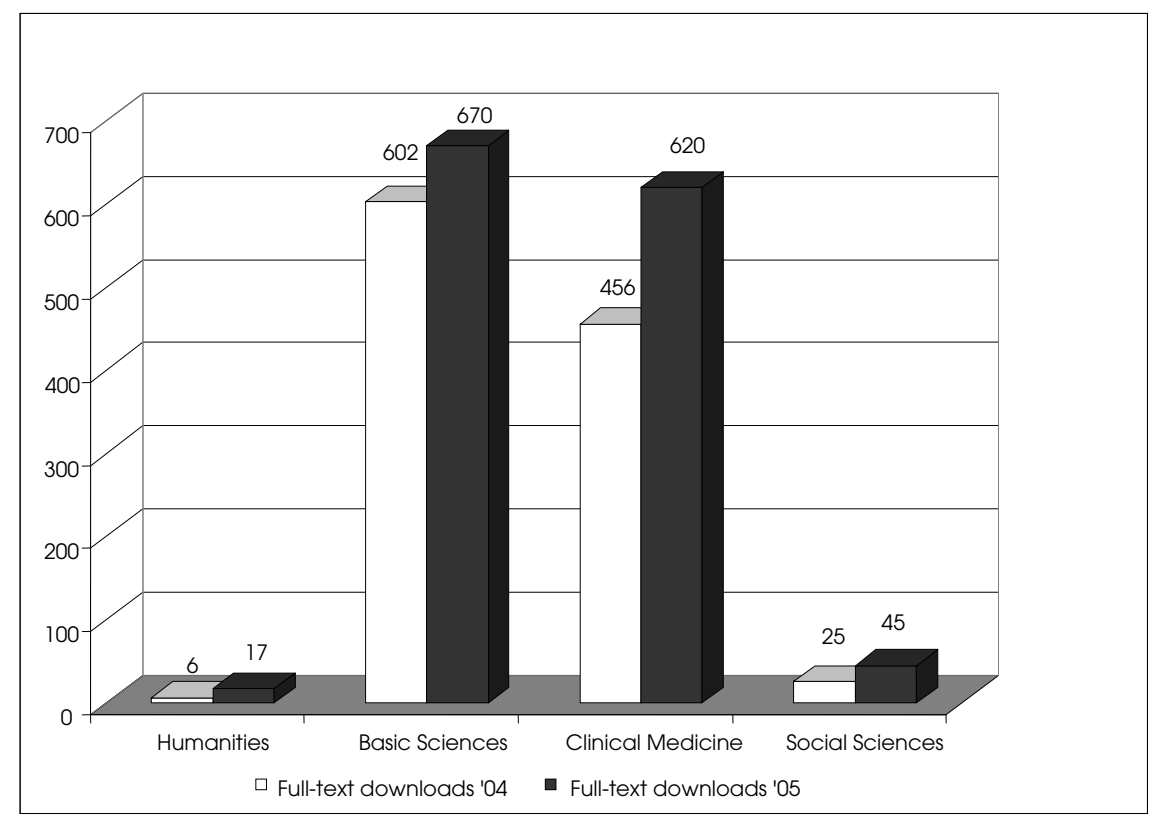

Figure 3. Comparison of full-text downloads by discipline 


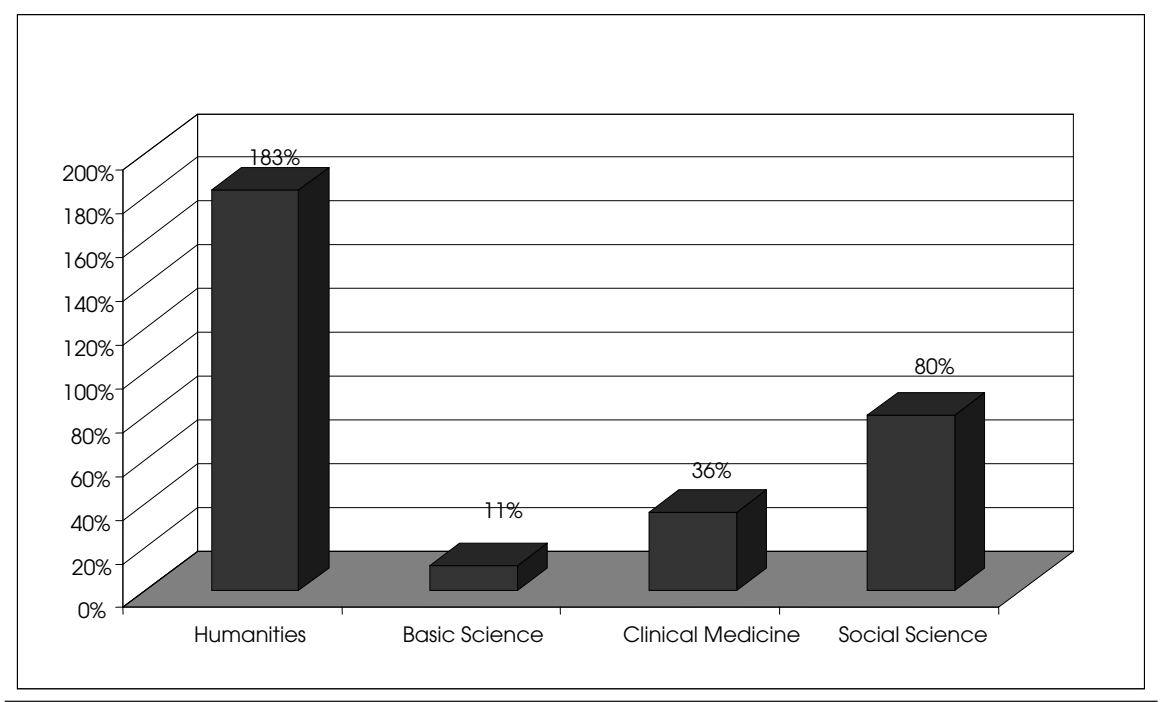

Figure 4. Comparison of use increase by discipline between 2004 and 2005

2004, 97 percent of the 1,089 full-text downloads occurred in the basic sciences and clinical medicine; in 2005, 95 percent of the 1,352 full-text downloads occurred in the basic sciences and clinical medicine.

Research data collected on the 682 titles in the sample show a significant difference in the user activity by discipline during the two years. Between 2004 and 2005, one sees an appreciably higher percentage of growth of full-text downloads in the humanities and social sciences (see figure 4). This notable increase in usage for the humanities (183 percent increase) and social sciences (80 percent increase) compared to the basic sciences (11 percent increase) and clinical medicine (36 percent increase) may be because users of basic sciences and clinical medicine resources have embraced online journals for a longer period of time; hence the percentage of growth in these disciplines is now less significant than within the humanities and social sciences. Another interesting facet in the difference between the user groups of HSCL and Smathers is revealed in the usage statistics: online journals as a whole were much less used by patrons of the Smathers Libraries than by

offered through the three largest pack- ages shows the benefits of the Big Deal arrangements for patrons accessing these titles. Based on a sample snapshot, the average price per fulltext download for online journals compared to the average cost of document delivery at HSCL reveals the significant benefit library patrons receives from Big Deal consortia agreements. While one cannot assume users would have requested all these articles through the document delivery services at HSCL the potential savings in document delivery fees (at $\$ 12$ per article) would be $\$ 774,072$-if all had been requested (see figure 5). Cost analyses are approximated but suggest that at the UF Libraries, that Big Deals offer a huge savings per download and access titles not available before the Big Deals were initiated.

While performing these studies, the team also attempted to trim unneeded, underused, and expensive online journals. Since cutting journal titles from Big Deal packages is difficult because of contractual obli-

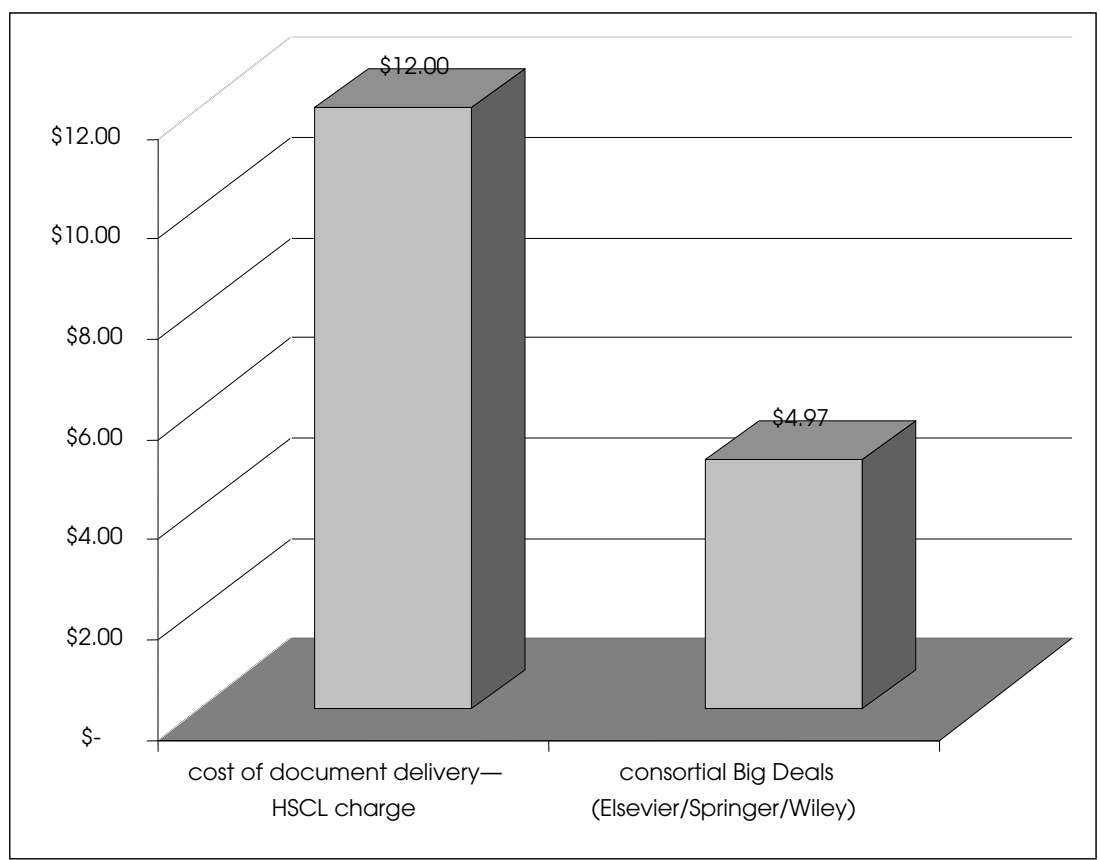

*Comparison uses 2005 composite data. Cost of downloads by Big Deal publishers range from $\$ 2.25$ to $\$ 7.82$ per download.

Figure 5. Comparison of costs for document delivery versus downloads from Big Deals 
gations, the team examined online journals received at HSCL from smaller or independent publishers hoping to save budget money by canceling titles. The team discovered very few titles received independent of the Big Deals that were both underused and expensive, concluding that canceling these titles would save little in the materials budget. Although this attempt to trim journal subscriptions did not identify titles to cancel, it did confirm that launching another cancellation project involving the smaller and independent publishers would not be worth the effort.

\section{Conclusion}

The research team developed a list comparing what was known going into the two studies and the surprises that came out of the findings; see appendix. One significant finding notes the relative cost-effectiveness of the electronic journal packages being received through the Big Deal, especially when these packages are measured by the number of full-text downloads compared to the cost of articles supplied by document delivery services at HSCL. Not only was there a demonstrated cost benefit for the UF Libraries through these Big Deals, the studies also showed a significant use of the titles not previously offered to library patrons and now being received through the bundled packages. The studies also determined an increase in users accessing the online journals across all four disciplines in the studies, although more usage is prevalent in the clinical medicine and basic sciences than in the humanities and social sciences. Of interest is that the largest jump of usage within the four disciplines occurred in the humanities and social sciences not clinical medicine and basic sciences.

Another key reason the team launched the studies was to explore the effects that the Big Deal licensing agreements were having on materials budgets and selection. Not only did the studies document the same trend in material expenditures for both HSCL and Smathers libraries, they illustrated the increasing strain being placed on the material budget. The cost of the Big Deals to the UF Libraries' materials budgets is ever increasing and may threaten the future of the print collection. With so much of the HSCL's materials budget being spent on electronic resources, an increasingly smaller percentage of funds are available to purchase other library materials. After reference and textbook purchases are made each fiscal year at HSCL, the remaining monographs funds are so limited that book selection by collection managers is a declining necessity. In 2005, Anderson wrote "five years from now, journal and database inflation will have outstripped library budget increases for so long that what was once seen as a coming crisis will be the new reality, and the primary topic of discussion. High usage of these expensive resources will make administrators reluctant to cancel them, leading to a long-overdue look at usage levels for printed monographs_-which, as we all know but don't like to say out loud, is very low. This will lead to drastic cuts in monograph budgets." ${ }^{23}$

What Anderson eloquently summarized is an important issue facing librarians. Data collected at the UF Libraries showed expenditures for online journals and databases continuing to rise while expenditures for print journals and print monographs declined. The area of most concern for the Smathers Library is the print monographs budget, which also has suffered from years of flat budgets that have adversely affected the growth of those collections. Although the expenditures for print journals are declining appreciably more than expenditures for print monographs, this is seen more as a period of transition as the library refocuses its primary collecting parameters from print to online journals. The UF Libraries have received little in the way of new allocations to cover the cost of electronic resources. As a result, the UF Libraries are facing the same issues and following the same spending patterns as many other academic and health science libraries in the United States. The two studies show that, despite a growing percentage of the materials budget being spent on online bundled packages, the Big Deal at the UF Libraries is a Good Deal if measured by overall use and by price per full-text downloads.

\section{References}

1. COUNTER: Counting Online Usage of NeTworked Electronic Resources, www.projectcounter.org (accessed Dec. 23, 2007).

2. Brinley Franklin and Terry Plum, "Library Usage Patterns in the Electronic Information Environment," Information Research 9, no. 4 (2004), paper 187, http://InformationR.net/ ir/9-4/paper187.html (accessed Dec. 5, 2006).

3. Martha Kyrillidou, "ARL University Libraries' Spending Trends," ARL Bimonthly Report 242 (Oct. 2005), www.arl.org/bm doc/rlbr242libspend .pdf (accessed Dec. 23, 2007).

4. Wilbur Cross, Dictionary of Business Terms (Englewood, N.J.: Prentice Hall, 1999): 85.

5. Ken Frazier, “The Librarians' Dilemma: Contemplating the Costs of the Big Deal," D-Lib Magazine 7, no. 3 (2001), www.dlib.org/dlib/march01/ frazier/03frazier.html (accessed Dec. 7, 2006).

6. Ibid.

7. Ken Frazier, "What's the Big Deal?" The Serials Librarian 48, no. 1/2 (2005): 52 .

8. Ibid.

9. Doris Small Helfer, "Is the Big Deal Dead? Status of the Crisis in Scholarly Publishing," Searcher 12, no. 3 (2004): 27-32.

10. Ibid., 32

11. Jeffrey N. Gatten and Tom Sanville, "An Orderly Retreat from the Big Deal: Is It Possible for Consortia?" D-Lib Magazine 10, no. 10 (2004), www.dlib.org/dlib/october04/ gatten/10gatten.html (accessed Dec. $6,2006)$.

12. Ibid. 
13. Ibid.

14. Loretta Ebert, "What's the Big Deal? 'Take 2' or, How to Make It Work for You .. . ., The Serials Librarian 48, no. 1/2 (2005): 62,66 .

15. Tim Bucknall, “The Big Deal: What's In It For Me?" Charleston Conference Proceedings 2005, ed. Beth R. Bernhardt, Tim Daniels, and Kim Steinle, 153-56 (Westport, Conn.: Libraries Unlimited, 2005): 156.

16. Bucknall, "Evaluating the Big Deal: The Carolina Consortium's Experience," Charleston Conference Proceedings 2005, ed. Beth R. Burnhardt, Tim Daniels, and Kim Steinle, 159-59 (Westport, Conn.: Libraries Unlimited, 2005).
17. Jason S. Price, "Making the Most of a 'Big Deal': Building a Consortial Shared List to Reclaim Title-by-title EJournal Selection for Libraries," Charleston Conference Proceedings 2005, ed. Beth R. Bernhardt, Tim Daniels, and Kim Steinle, 160-72 (Westport, Conn.: Libraries Unlimited, 2005).

18. Ibid., 172.

19. Brinley and Plum, "Library Usage Patterns."

20. Alfred B. Kraemer, Paula Sullenger (recorder), "Making the Most of Your Usage Statistics," The Serials Librarian 48, no. 3/4 (2005): 297.

21. Carol Hansen Montgomery and Donald W. King, "Comparing Library and User Related Costs of Print and Electronic Journals Collections: A First Step Towards a Comprehensive Analysis," D-Lib Magazine 8, no. 10 (Oct. 2002), www.dlib.org/dlib/ october02/

montgomery/10montgomery.html (accessed Dec. 5, 2006).

22. James A. Stemper and Janice M. Jaguszewski, "Usage Statistics for Electronic Journals: An Analysis of Local and Vendor Counts," Collection Management 28, no. 4 (2003): 4.

23. Rick Anderson, Charleston Conference 25th Anniversary Memory Book [CD-ROM] (Charleston, S.C.: Memory Book Committee, 2005).

\section{Appendix. What We Knew and What Surprised Us}

\section{What we knew:}

Numerous studies confirm that library patrons and researchers access health, medical, and general sciences library resources substantially more than library patrons who access resources in the humanities and social sciences do.

\section{What we learned or surprised us:}

Throughout both studies, usage statistics for Smathers online journals were still significantly below those of the HSCL, despite the fact that stacks in Smathers were closed due to a massive building renovation.

\section{What we knew:}

The Big Deal and consortia packages for online resources are siphoning an increasingly larger percentage of the library budget.

\section{What we learned or surprised us:}

Despite the HSCL's large expenditure for Big Deal packages, when considering the relatively low cost-per-article and access to increased numbers of online journals the UF Libraries' patrons are receiving, the Big Deals in many cases are Good Deals.

\section{What we knew:}

The HSCL subscribes to online resources that are both underutilized and too expensive to be cost-effective and therefore should be reviewed for cancellation.

\section{What we learned or surprised us:}

After eliminating Big Deal package titles for individual cancellation, due to stipulated licensing agreements, we examined online journal subscriptions from independent publishers and discovered few titles that are both underused and expensive; thus, such cancellations would save little on the budget.

\section{What we knew:}

Approximately 10 percent of the HSCL's materials budget is spent on monographs, and after reference and text book purchases are made each fiscal year, the remaining monograph funds are so limited that book selection by collection managers is almost extinct.
What we learned or surprised us:

The current trend of expenditures seen in the HSCL's materials budgets from fiscal years 2002/03 through 2005/06 (i.e., a dramatic increase in expenditures for online journals, a decrease in expenditures for print journals, and flat line expenditures for print monographs) is mirrored almost exactly by the Smathers' materials budgets for the same time span.

\section{What we knew:}

Traditionally, libraries have always accepted the $80 / 20$ rule (20 percent of the collection gets 80 percent of the use) as being the yardstick for general use of print journal collections.

\section{What we learned or surprised us:}

According to UF Libraries usage statistics of online journals, the $80 / 20$ rule is more of an 80/30 or $80 / 40$ rule. 